\title{
Stress and Burnout in Nursing Profession
}

\author{
Suprakash Chaudhury* and Swaleha Mujawar \\ Department of Psychiatry, Dr DY Patil Medical College, Hospital \& Research Center, India
}

Submission: February 27, 2018; Published: March 06, 2018

*Corresponding author: Suprakash Chaudhury, Department of Psychiatry, Dr DY Patil Medical College, Hospital \& Research Center, India, Email: suprakashch@gmail.com

\section{Short Communication}

Stress, described by Lazarus as "a particular relationship between the person and the environment that is appraised by the person as taxing or exceeding his or her resources and endangering his or her well-being [1]," has been regarded as an occupational hazard since the mid-1950s [2]. Health professionals, being responsible for the health of others are under the pressure of different stressors [3]. Nursing has been regarded as a particularly stressful profession. The stressful factors in this job have affected nurses in a serious way [4]. Work stress in nursing was first evaluated in 1960 when Menzies recognised four sources of anxiety among nurses: patient care, decision making, taking responsibility, and change [5]. The highest rate of job stress is in the 25-29 age groups and minimum in the 35 and above ages. This may be related to greater consistency and increase in their skills and work experience due to increasing age [6]. Stressors for nurses identified by various studies include care about patients, knowledge, skill and tasks of nurses and policies, relation with mangers and coworkers, noises, light, shift duty and frequent night shifts [7-10]. Abdi and Shahbazi also showed that physical environment, responsibility and range of roles are the most important sources of stress [11]. Elder showed in his study that the effect of coworkers, heads and workloads was important factors of job stress. The demographic factors were not very important [12]. On the other hand Khaqhanizadeh et al. [13] showed a relation between marital status and job stress of nurses. Personality traits are also factors in the development of stress since what is exciting to one person may be overwhelming to another [14]. A meta analysis of 20 studies on the effect of factors on job stress revealed that attitude toward job (participation in making decisions, satisfaction, job commitment) and some special aspects (dangers and hardships of a job), are the most powerful factors that affect job stress [15]. Other studies have mentioned workload, roles and services in units with high work load as sources of job stress in nurses [16,17].

The term "burnout" was coined by Freudenberger In 1974 to describe a state of physical, mental, and emotional exhaustion that often results from a combination of very high expectation and persistent situational stress. Nursing profession has been considered to be highly susceptible to burnout due to work overload, inter-professional conflict, lack of clarity, task ambiguity, increasing complexity of the tasks, patients' emotional demands, and with patients' poor prognosis. Age, duration of total period of nursing, locus of control, sense of general well-being, adjustment capabilities, and emotional maturity were found to have significant relation with burnout [18]. Job stress can result in lack of health and even hurting people [19]. Stress among nurses causes tiredness, harsh behaviour, anxiety, increase of blood pressure, lack of self-confidence, lack of job satisfaction, and decrease in efficiency [20]. It can lead to depression, isolation from patients, absence and decrease of their qualification, absenteeism and turnover, and consequently detract from the quality of care $[21,22]$. Is there any solution to the problems of stress and burnout in nursing profession? By turning work environments into healthy workplaces, researchers and nurse leaders believe that improvements can be realized in recruitment and retention of nurses, job satisfaction for all health care staff, and patient outcomes-particularly those related patient safety [23]. In another study, a general construct labelled "organizational support" revealed the expected negative relationship with work exhaustion [24]. Likewise, social support from supervisors or colleagues demonstrated a negative association with work stress. and burnout $[25,26]$. There was a direct and beneficial effect of social support on workers' psychological well-being and organizational productivity [27]. Work empowerment showed a strong, negative association with job tension and a strong positive relationship with perceived work effectiveness [28,29]. As perceptions of empowerment increased, staff nurses reported less emotional exhaustion and depersonalization along with a greater sense of personal accomplishment-the three components of burnout [30]. Managerial support and participative management reduced stress $[31,32]$. Thus, institutional leaders need to understand their financial standing and also need to assess how environmental stress is affecting patients and staff and thereafter take action to alter these situations.

\section{References}

1. Lazarus RS, Folkman S (1984) Stress, appraisal and coping. Springer, New York, USA. 
2. Kahn RL, Wolfe DM, Quinn RP (1964) Organizational stress: studies in role conflict and ambiguity. Wiley, New York, USA.

3. Bratt MM, Broome M, Kelber S, Lostocco L (2000) Influence of stress and nursing leadership on job satisfaction of pediatric intensive care unit nurses. Am J Crit Care 9(5): 307-317.

4. Golshiri P, Pourabdian S, Najimi A, Zadeh HM, Hasheminia J (2012) Job stress and its relationship with the level of secretory IgA in saliva: a comparison between nurses working in emergency wards and hospital clerks. J Pak Med Assoc 62(3-2): S26-S30.

5. Menzies IEP (1960) Nurses under stress. Internatl Nurs Rev 7: 9-16.

6. Khodaveysi M, Mohammadi N, Omidi A (2005) Assessment of job stress in nurses. Scientific Journal of Hamadan Nursing \& Midwifery Faculty 13(2): 44-50.

7. Bailey RD (1985) Coping with Stress in Caring. Blackwell Scientific, London.

8. Cooper CL, Sutherland VJ (1987) Job stress, mental health, and accidents among offshore workers in the oil and gas extraction industries. J Occup Med 29(2): 119-25.

9. Chaudhury S, Augustine M (1993) Psychophysiological effects of night shift in nursing officers. Industrial Psychiatry Journal 6: 20-26.

10. Chaudhury S, Jyothi SG (1996) Night shift intolerance in nursing officers reassessed. Med J Armed Forces India 52: 207-8.

11. Abdi H, Shahbazi L (2001) Occupational stress in nurses working in ICU and its relationship with burnout them. J Shaheed Sadoughi Univ Med Sci 9(3): 58-63.

12. Elder S (2004) Occupational Stress in Nursing A Meta-analytic Investigation of Occupational Stress and Related Organizational Factors: Is Nursing Really a Uniquely Stressful Profession [PhD Thesis] Queensland: School of Psychology (Health). University of Southern Queensland, Australia.

13. Khaghani Zadeh M, Ebadi A, SiratiNayer M, Rahmani M (2012) Relationship between job stress and quality of work life of nurses in selected hospitals armed force. J Mil Med 10(3): 175-84.

14. French JRP, Caplan RD (1972) Organizational stress and individual strain. In: Marrow AJ [Eds.], The failure of success, AMACOM, New York, USA, pp. 30-66.

15. Dowden C, Tellier C (2004) Predicting work-related stress in correctional officers: A meta-analysis. J Crim Just 32(1): 31-47.

16. Muncer S, Taylor S, Green DW, McManus IC (2001) Nurses' representations of the perceived causes of work-related stress: A network drawing approach. Work \& Stress 15(1): 40-52.

17. Kipping C (2000) Stress in mental health nursing. JInt J Nurs Stud 37(3): 207-18.
18. Chakraborty R, Chatterjee A, Chaudhury S (2012) Internal predictors of burnout in psychiatric nurses: An Indian study. Ind Psychiatry J 21: $119-24$.

19. Clegg AJ (2001) Occupational stress in nursing: a review of the literature. Nurs Manag. 9(2): 101-6.

20. Hashemzadeh I, Owrangi M, Bahrehdar MJ (2000) Job stress and its relation with psychological health among the hospital personnel. Shiraz. J Psychiatry Clin Psychol 6(2-3): 55-62

21. McGrath A, Reid N, Boore J (2003) Occupational stress in nursing. Int J Nurs Stud 40(5): 555-65.

22. Jennings BM (1994) Stressors of critical care nursing. In: Thelan LA, Davie JK, Urden LD [Eds.], Critical care nursing Diagnosis and management, St Louis, MO, Mosby, USA, pp. 75-84.

23. McCauley K, Irwin RS (2006) Changing the work environment in intensive care units to achieve patient-focused care: the time has come. Am J Crit Care 15: 541-548.

24. Blau G, Tatum DS, Ward Cook K (2003) Correlates of work exhaustion for medical technolgists. J Allied Health 32(3): 148-157.

25. Johnson JV, Hall EM, Ford DE (1995) The psychosocial work environment of physicians. The impact of demands and resources of job dissatisfaction and psychiatric distress in a longitudinal study of Johns Hopkins medical school graduates. J OccEnv Med 37(9): 11511159.

26. Hillhouse JJ, Adler CM (1997) Investigating stress effect patterns in hospital staff nurses: results of a cluster analysis. Soc Sci Med 45(12): 1781-8.

27. Park K, Wilson MG, Lee MS (2004) Effects of social support at work on depression and organizational productivity. Am J Health Behav 28(5): 444-455.

28. Laschinger HK, Havens DS (1997) The effect of workplace empowerment on staff nurses' occupational mental health and work effectiveness. J Nurs Adm 27(6): 42-50.

29. Laschinger HK, Wong C, McMahon L (1999) Leader behavior impact on staff nurse empowerment, job tension, and work effectiveness. J Nurs Adm 29(5): 28-39.

30. Hatcher S, Laschinger HKS (1996) Staff nurses' perceptions of job empowerment and level of burnout: a test of Kanter's theory of structural power in organizations. Can J Nurs Adm 9(2): 74-94.

31. Weinberg A, Creed F (2000) Stress and psychiatric disorder in healthcare professionals and hospital staff. Lancet 355(9203): 533537.

32. Leveck ML, Jones CB (1996) The nursing practice environment, staff retention, and quality of care. Res Nurs Health 19(4): 331-343.

\section{Your next submission with Juniper Publishers} will reach you the below assets

- Quality Editorial service

- Swift Peer Review

- Reprints availability

- E-prints Service

- Manuscript Podcast for convenient understanding

- Global attainment for your research

- Manuscript accessibility in different formats

( Pdf, E-pub, Full Text, Audio)

- Unceasing customer service

Track the below URL for one-step submission https://juniperpublishers.com/online-submission.php 